\title{
Review: Prof. Ratzel's Comparative Geography
}

Author(s): H. R. M.

Review by: H. R. M.

Source: The Geographical Journal, Vol. 19, No. 4 (Apr., 1902), pp. 500-501

Published by: geographicalj

Stable URL: http://www.jstor.org/stable/1775250

Accessed: 26-06-2016 23:06 UTC

Your use of the JSTOR archive indicates your acceptance of the Terms \& Conditions of Use, available at

http://about.jstor.org/terms

JSTOR is a not-for-profit service that helps scholars, researchers, and students discover, use, and build upon a wide range of content in a trusted digital archive. We use information technology and tools to increase productivity and facilitate new forms of scholarship. For more information about JSTOR, please contact support@jstor.org.

The Royal Geographical Society (with the Institute of British Geographers), Wiley are collaborating with JSTOR to digitize, preserve and extend access to The Geographical Journal 
line of Syria." If not a direct cause, this state of things at least indirectly contributed to the shifting of maritime enterprise to the other end of the Mediterranean, and to schemes for reaching India and the farther East by sailing out through the strait of Gibraltar. Mr. Beazley's concluding chapter deals with geographical theory and description during the central middle age. Foremost among the geographers of the time stands the emperor Constantine Porphyrogennetos, whose treatise ' On the Public Administration of the Empire' not only minutely describes the empire itself with its vassal states, but abounds in information about the barbarian regions to the north and east. After devoting nearly fifty pages to an analysis of this extremely interesting document, Mr. Beazley passes on to Adam of Bremen, the first pioneer in the long series of German geographers, and concludes his volume with an examination of the extant maps of the period, the oldest of which, the 'Anglo-Saxon' Map of the World, drawn by an Irish monk, and now in the British Museum, he attributes to the time of Archbishop Sigeric of Canterbury (992-994). The photographic facsimiles of this, and of the sixteen other contemporary maps, including four maps by Matthew Paris-the 'England,' the 'World Map,' the 'Itinerary,' and the 'Palestine'-will furnish an abundant feast to the numerous amateurs of historical cartography.

\section{E. J. Payne.}

\section{Prof. Ratzel's Comparative Geography.*}

The scope and bearing of Prof. Ratzel's new book cannot be fully understood from the first volume. In the preface he refers to it as a "Comparative Geography " in Ritter's sense of the term, dealing, that is to say, with the interrelations of the phenomena of the Earth, and therefore looking at the general rather than the special aspect of geography. The work is not a student's text-book like Wagner's 'Lehrbuch'; it partakes rather of the character of Reclus' 'La Terre,' being written apparently for the intelligent general reader sufficiently interested in the subject to attack a considerable mass of printed matter, but not requiring the aid of frequent references to authorities. In fact, at the first inspection, 'Die Erde und das Leben' shows a freedom from footnotes that would be surprising did the preface not promise a list of works consulted in the second volume.

The portion of the work now before us gives a brief but luminous summary of the history of geography, turning over the familiar facts with the ease and freshness that only a specialist leading up to his special study can command. Then follows an account of the Earth as a planet and as a physical body, succeeded by chapters on volcanic phenomena, the movements of the Earth's crust, and the origin of mountains. The remaining two-thirds of the volume are devoted to what we may call physical geography in the particular meaning of the word.

Land and water, islands, coast-lines, geological processes, and land-forms are handled with an absence of technicality and a literary grace that we do not always find in German geographical works, but there is no want of precision as to facts. In discussing the various features, reference is made in many cases to their influence on human movements, and the broader human interests which unite all intellectual studies are not forgotten. This aspect of the subject will be developed more fully in the second volume, which will deal with the oceans and the atmosphere, and culminate in Prof. Ratzel's special sphere of Life and Man.

The illustrations are very numerous, and almost all strikingly good, the clear sketch-maps as well as the photographs. A series of coloured plates is an attractive

* 'Die Erde und das Leben.' Eine vergleichende Erdkunde von Prof. Dr. Friedrich Ratzel. Erste Band. Leipzig und Wien : Bibliographisches Institut. 1901. 
feature, and so is the simple but beautiful design of the binding. We trust that the second volume will be provided with a full index, and we venture to hint that the list of works consulted might be more carefully considerea from the points of view of selection and arrangement than that given on p. 66 .

H. R. M.

\section{THE MONTHLY RECORD.}

\section{EUROPE.}

Ingleborough. - Few maps of the Ordnance Survey show more interesting features than Nos. 50 and 60 of the Hawes and Settle districts. Prof. Hugbes of Cambridge has a valuable account of the physical geography of the Ingleborough neighbourhood in the Proceedings of the Yorkshire Geological and Polytechnical Society (vol. xiv. pp. 125-150). He says that he knows of no district in which the ordinary and exceptional operations of denudation can be better studied. It illustrates remarkably the effects of "the condensation of the moisture of the winds on the cold rocks working where no rain can reach; the action of water more or less charged with acids on the limestones; the fantastic forms which are thus produced ; the effect of this action on a larger scale in the formation of potholes and of underground channels and of valleys by the falling in of caves; the breaking-up of great masses of jointed rock under the influence of frost and the masses that in the thaw are carried over the frozen snow that fills the place where the talus should rest, and form crescentic masses lying some way in front of the cliff ; the cutting back of gorges by the removal of block after block, first detached by complex denudation, then lifted out of their bed by the hydrostatic paradox and hurled over the edges of the cliff."

The Cheddar Gorge.-In the February number of the Geological Magazine, Dr. C. Callaway calls attention to the zigzag course of the Cheddar gorge as almost certainly due to the jointing of the carboniferous limestone through which the river there flows. This is traversed by two systems of joints, apparently nearly vertical, and intersecting approximately at a right angle, the stone readily breaking away, when quarried, in cubical blocks. That the course of the gorge is due to these joints is supported by the fact that the marked zigzags cease at the end of the gorge, just where the limestone gives place to the Trias, in spite of the more gradual fall in the river-bed during its passage across the latter formation. Dr. Callaway shows that the explanation will hold equally well whether the gorge is supposed to have been cut by a stream flowing above ground or below the surface, though he inclines to the latter view of its mode of origin.

Rainfall Maps of Brandenburg and Pomerania.-The most recent addition to Prof. Hellman's series of rainfall maps of northern Germany, which makes a gradual progress westward from the extreme east, includes the provinces of Brandenburg and Yomerania. The map shows the average rainfall for the ten years 1891 to 1900 , a period which comparison with the long-period average of a few stations within the area shows to approximate very closely to the mean. Speaking generally, the greatest amount of rainfall is recorded on the eastern, soutbern, and western boundaries of the district represented, while the smallest occurs near the middle, in the valley of the Oder. The short paper which accompanies the map deals chiefly with the variations of yearly amounts from the mean, and with the frequency of occurrence of heavy falls of rain. It appears that the average rate of fall per minute is twice as great for showers lasting under an hour, and four times as great for showers lasting less than a quarter of an hour, than for steady rain lasting over three hours. The map is based on the records 